\title{
Effects of Supply Determinants on Supply Performance of Slaughter Animal for Meat Export Abattoirs in Ethiopia
}

\author{
Lelisa Gudisa \\ Ethiopian Meat and Dairy Industry Development Institute, Market Research Directorate \\ Bishoftu, Ethiopia
}

Received: August 19, 2021

Accepted: September 9, 2021

Online Published: October 16, 2021

doi:10.11114/bms.v7i4.5378

URL: https://doi.org/10.11114/bms.v7i4.5378

\begin{abstract}
This study was attempted to look at effects of supply determinants on supply performance of slaughter animal for meat export abattoirs in Ethiopia. Explanatory type of research design was used to explore the relation between dependent and independent variables. The research was supported by primary and secondary data. The primary data obtained through structured questionnaire prepared for export abattoirs and slaughter animal suppliers, whereas the secondary data obtained from published and unpublished documents. Sixty (60) respondents from ten (10) meat export abattoirs which are at managerial positions and sixty (60) managers of slaughters animal suppliers and the total number of respondents were one hundred twenty (120). The study used brokers' involvement in supply, transportation facility, price of slaughter animal, illegal live animal export, and quality of slaughter animal, sustainability of slaughter animal supply and traditional livestock production system as independent and supply performance as dependent variable. Correlation analysis was accustomed to analyze relation between independent and dependent variables whereas multiple regressions were applied to analyze and identifies impact level of every independent on dependent variable. The study found that sustainability of slaughter animal supply, traditional livestock production system; transportation facility and quality of slaughter animal have strong effect on supply performance in positive direction respectively. Brokers involvement in supply, price of slaughter animal and illegal live animal export also have strong effect on supply performance in the negative direction.
\end{abstract}

Keywords: slaughter animals, supply determinants, supply performance, meat export abattoirs, animal suppliers

\section{Introduction}

\subsection{Background of Study}

Ethiopia is believed to have the largest livestock population in the world and Africa. The latest animal population census CSA (2016/17) shows that Ethiopia has 59.5 million cattle, 30.7 million sheep, 30.2 million goats, 2.4 million camels. The livestock sector has been contributing considerable portion to the economy of the country, and still promising to rally round the economic development of the country. According to FAO (2013) it contributes 12 and 33\% of the total agriculture and Gross Domestic Product (GDP), respectively, and provides livelihood for $65 \%$ of the population. The sector also accounts for $12-15 \%$ of the total export earnings.

There is high demand for live animals as well as meat from small ruminants by consumers in the Middle East and North and West African countries and also a high domestic demand for small ruminant meat, particularly during religious festivals (Amha, 2008 and Anteneh, 2019). The country has been earning foreign currency by exporting meat (mainly chilled shoats' carcass) and live animals namely cattle, sheep, camels and goats to major destination markets of United Arab Emirate (UAE), Kingdom of Saudi Arabia (KSA), Vietnam, Bahrain, Hong Kong and Nigeria (EMDIDI,2019).

According to Gezehany (2019) report in 2018/2019 Ethiopia have got (195.17 million USD) by exporting livestock products which were $8.5 \%$ share from the whole country's export in general. Ethiopia exports approximately 20,000 tones meat and meat products annually. It has about (92.65 million USD) $47.5 \%$ share from the whole livestock products (meat, leather, milk, bee products) export in the same year. From this about 80.35 million USD (86.7\%) gained from sheep and goat meat, 6.2 million USD (6.73\%) from beef and 6.06 million USD $(6.55 \%)$ was gained from slaughter by-products export.

Due to different promotion efforts made by the government to attract foreign and local investors to invest on 
agro-processing industries, large livestock population with diverse and adaptable genotypes, diverse agro-ecologies for production of different types of livestock, proximity location to Middle East and GCC countries market which have potential demand for meat, many private investors now are engaged in meat export industries (Getnet, 2017, Gezhany, 2019).

Before 1990 it was a stage of development in the country in which there was only one company exporting meat to the global market especially the Middle East and some African countries (EMDIDI, 2018). Gradually, the number of modern livestock product industries, particularly meat export firms established in the country has been on the raise. In 2007/08 there were four meats export abattoirs with estimated total capacity of production 30,380 tons per year, of which 23,180 tons of sheep and goat and 7,200 ton beef. The meat export performance was about 6,488.74 metric ton of meat and edible meat by-products and generates (20.85 million USD) by the referred year. According to Gezahany (2019) currently, the number of meat export abattoirs increased to thirteen (13) with annual estimated production capacity of 200, 300 ton sheep and goats' meat and 130,411 ton beef per a year. This shows that, they need $(10,739,125$ head) live animals, $(9,435,015$ head sheep and goats, and 1,304,110 head beef) to use as an input per a year.

\subsection{Statement of the Problem}

In Ethiopia there are thirteen (13) meat export abattoirs with annual estimated production capacity of 200, 300 ton sheep and goats' meat and 130,411 ton beef per a year. This shows that, they need 10,739,125 head live animals, 9,435,015 head sheep and goats, and 1,304,110 head beef to use as an input per a year.

However, the country cannot use this opportunity and the average annual capacity utilization of an abattoir per year is not more than 40\% (Gezehany, 2019). It is slightly similar to Eyob Gebregziabear (2018), who reported despite the ever increase demand in importing countries and huge livestock resources of Ethiopia, the existing meat export abattoirs are operating at below $50 \%$ of their installed capacity and could not satisfy this demand. According to (USIAD, 2010) abattoirs frequently complain of a lack of supply, particularly for sheep and goats, even as pastoralists complain of low prices due to a lack of demand.

Unless this problem was properly identified and addressed accordingly it was difficult to gain the contribution of sector to country's economy at expected level. Therefore, this was the main reasons why the researcher decided to conduct this study; specifically, assessment of effect of supply determinants on supply performance of slaughter animal for meat export abattoirs in Ethiopia to identify the problem clearly.

\subsection{Research Hypothesis}

Based up on empirical evidences such as; AACCSA (2015), Mbekeani and Bacchetta (2007), Kefyalew and Tarekegn (2013), Reddy and Kanna (2015), Evans \& Lindsay (2002), Fred Appiah Fening (2012) and Steinfeld (2006) the researcher developed the following alternative hypothesis.

$\mathbf{H}_{1}$ : Broker's involvement in slaughter animal supply has negative and significant effect on supply performance of slaughter animal.

$\mathbf{H}_{2}$ : Appropriate transportation facility has positive and significant effect on supply performance of slaughter animal.

$\mathbf{H}_{3}$ : Price of slaughter animal has negative and significant effect on supply performance of slaughter animal.

$\mathbf{H}_{4}$ : Illegal live animal export has negative and significant effect on supply performance of slaughter animal.

H5: Quality of animal supply has positive and significant effect on supply performance of slaughter animal.

H6: Sustainability of animal supply has positive and significant effect on supply performance of slaughter animal.

$\mathbf{H}_{7}$ : Traditional Livestock production system has positive and significant effect on supply performance of slaughter animal.

\subsection{Objectives}

1.4.1 General Objective the Study

The main objective of the study was to examine effects of supply determinants on supply performance of slaughter animal for meat export abattoirs.

\subsubsection{Specific Object of the Study}

1) To examine the relationship between supply determinants and supply performance of slaughter animal for meat export abattoirs

2) To examine the extent effects of supply determinants on supply performance of slaughter animal for meat export abattoirs 


\subsection{Significance of the Study}

This study may contribute the following significance towards different stakeholders.

$>$ It enables owners and managers of meat export abattoirs and live animal suppliers to know which supply determinants had effect on supply performance of slaughter animal for meat export abattoirs in order to take mitigation measures and enhance competitiveness.

$>$ The study used as an input for policy makers in the livestock sector especially for Ministry of Agriculture, Ministry of Trade and Industry, Ethiopia Meat and Dairy Industry Development Institute in the development of meat sub- sector long term policies and strategies which ensure continue and sustainable supply of slaughter animal for meat export abattoirs.

$>$ The result also used for international donors and other stakeholders working in livestock development as an intervention area for their developmental support.

$>$ The study provide information for export abattoirs which are currently under construction and those want to join as slaughter animal suppliers in order to understand and prepare themselves for the likely factors which would determine their supply performance.

$>$ Finally, this study result might also initiate me and other researchers to conduct different research works from different perspectives, which may contribute for strengthening of the value-chain of the meat export abattoirs in the meat market.

\section{Review of Related Literature}

\subsection{Determinants of Supply Performance}

Supply is the total amount of a product (good or service) available for purchase at any specified price. According to Sugiarto, et al (2005) stated that the supply of a product is determined by various factors, namely: the price of the product itself, the price of other products, the production costs, the objectives of producer/company, the technological level, the season, etc. Supply determining factors include: cost and accessibility of consumer goods, farm subsidies, and road infrastructure (including its quality) and services such as marketing or credit (FAO, 2010).

According to Hassen et al (2015) the key determinants of supply performance are (i) Domestic transport infrastructure which include the availability of physical infrastructure, ranging from roads and ports to energy and telecommunications (ii) Macroeconomic environment which include the real exchange rate, which reflects the underlying relative movement of prices at home and abroad, proves to have a significant effect on the export performance of a country (iii) Foreign direct investment (FDI) which includes foreign capital inflow and knowledge-based industries (IV) Institutions).

Good supply performance and a high-quality, sustainable product can also help a company to reduce the risk of conflict or problems with suppliers, governments, staff and local communities, customers and improve its status as a respected partner in destinations (Veckery, 1999). In this regard, capital, information, raw material, intermediate goods, and such determine the form of the collaboration between the businesses (Tabibi, Mazlumi, 2009).

\subsection{Overview of Global Meat Production and Export Performance}

Meat production of the world increased by 1.0\% to $327 \mathrm{Mt}$ in 2018 from 2017, reflecting increases in the production of beef, pig and poultry meats, with very modest gains in sheep meat. Much of the world meat production increase occurred in Australia, the European Union, the Russian Federation, and the United States, and to a certain extent in Argentina, India, and Mexico. Meat output, however, declined marginally in the China and Brazil, two of the largest meat producers in the world, slowing the pace of the overall global increase. Meat output increase is largely attributable to productivity improvements, but in several cases, in particular Australia and the European Union, the higher rate of drought-induced slaughter was a factor. In the case of China, the slower growth in meat output was mainly the result of a decline in pig meat output due to the outbreak of African Swine Fever (ASF), and the output decline in Brazil was largely caused by a loss of export markets, especially that of the Russian Federation, due to an import embargo triggered by food safety concerns (FAO, 2019).

According to FAO (2019) world total meat exports also increased to $34 \mathrm{Mt}$ in 2018, up 1.5\% from 2017. In 2018, export expansion was mainly driven by increased shipments from Australia, Argentina, Thailand, and the United States, but offset by declines in Brazil and India. On imports, China, the world's largest meat importer, increased its purchases significantly as consumer demand for meat continued to rise amid a contraction in domestic pig meat output. 
The average of international meat prices in 2018 were $2.2 \%$ lower than in 2017 , reflecting the decline in annual average prices of pig and poultry meats, while those of beef remained stable. Total meat production of the world is projected to expand by more than $40 \mathrm{Mt}$ by 2028 , reaching nearly $364 \mathrm{Mt}$. Overall, the bulk of meat production growth is attributed to developing region, which will account for $74 \%$ of the additional output, but the increase in production will vary according to the region. In some developing countries, production growth is supported by increasing productivity in the form of higher carcass weight per livestock unit and improving feed use efficiency. However, productivity in the least developed countries (LDCs) is not projected to improve at the same rate as smallholder structures and lack of investment in the livestock sector will continue to limit technological improvements and commercialization(FAO, 2019)

\title{
2.3 Overview of Ethiopian Meat Production and Export Performance
}

Ethiopia have huge livestock wealth inventory in the world. The latest animal population census CSA (2016/17) shows that Ethiopia has 59.5 million cattle, 30.7 million sheep, 30.2 million goats, 2.4 million camels. Livestock in Ethiopia provides draught power, income to farming communities, means of investment and important source of foreign exchange earning to the nation. At a national level, livestock is the source of industrial raw materials (milk, meat, hides and skin) and high value protein to potential consumers in Ethiopia. According to FAO (2013) livestock contributes 12 and 33\% of the total and agricultural Gross Domestic Product (GDP), respectively, and provides livelihood for $65 \%$ of the population. The sector also accounts for $12-15 \%$ of the total export earnings.

According to Eshetie T et al (2018) having diverse livestock resources to gather with its strategic location, Ethiopia has got more advantage to market livestock and livestock products to wider parts of the world than most African countries. Ethiopia's livestock sector's growth and future prosperity is closely linked to the slaughter houses' ability to seize opportunities arising from changing global economies through forging long-term and meaningful relationships with key international partners, including the Middle East and Gulf Cooperation Council (GCC) countries. The major and formal meat export destination from Ethiopian export abattoirs for chilled small ruminant meat is limited to United Arab Emirates and Kingdom of Saudi Arabia with the order of $60 \%$ and $38 \%$ share (Eshetie T et al, 2018).

Before 1990 it was a stage of development in the country in which there was only one company exporting meat to the global market especially the Middle East and some African countries. Gradually, the number of modern livestock product industries, particularly meat export firms established in the country has been on the raise. In 2007/08 there were four meats export abattoirs with estimated total capacity of 30,380 tons per year, of which 23,180 tons of sheep and goat, and 7,200 ton beef. The meat export performance was about 6,488.74 metric ton of meat and edible meat by-products and generates (20.85 million USD) by the referred year. According to Gezahany (2019) currently, the number of meat export abattoirs increased to thirteen (13) with estimated annual production capacity of 30,380 ton per year to 200, 300 ton sheep and goats' meat and 130,411 ton beef meat production capacity per a year.

\subsection{Conceptual Frame Work}

Ethiopian meat export abattoirs were under-utilized their capacity. Therefore, effort was made to identify effects of supply determinants on supply performance of slaughter animal for meat export abattoirs in Ethiopia. Accordingly, the conceptual frame work was designed from the research question of the research which in turn conceptualized from literatures and practical experience.

In the conceptual frame work; different supply determinants are supposed to have effect on supply performance of slaughter animals for meat export abattoirs.

\section{Independent Variables}

\section{Dependent variable}

\author{
Broker's involvement in supply \\ Appropriate Transportation \\ Price of slaughter animal \\ Illegal live animal export \\ Quality of animal supply \\ Sustainability of animal supply \\ Traditional Livestock production system
}

Figure 1. Conceptual framework

Source: (Eyob et al, 2016, Eshete et al, 2018, Gezhany, 2019) 


\section{Research Methodology}

\subsection{Research Design}

In this study explanatory research design were used. Correlation analysis was used to analyze relation between dependent and independent variables whereas multiple regressions were applied to analyze and identify impact level of each independent variable on dependent variable (supply performance).

\subsection{Population, Sampling Techniques and Sample Size}

\subsubsection{Population of the Study}

Target population of this study would be all meat export abattoirs and slaughter animal suppliers. The study covers all meat export abattoirs currently operation which were thirteen (13) in numbers and total number of slaughter animal suppliers engaged in the supply of slaughter animals were sixty (60).

\subsubsection{Sampling and Sample Size}

Using census method all meat export abattoirs were included in the study except Jigjiga, Abergel and Helmex meat export abattoirs which were stopped meat export. Purposively sixty (60) respondents from ten (10) meat export abattoirs those have relevant information and sixty (60) managers of slaughters animal suppliers and totally 120 respondents were used.

\subsection{Data Source}

Both primary and secondary data were used. The primary data was collected from ten (10) meat export abattoirs and sixty (60) slaughter animal suppliers while secondary data was collected from reports.

\subsection{Data Collection Instruments}

In this study closed-ended questionnaires were prepared. The respondents were requested to indicate their feeling on a five point Likert scale.

\subsection{Validity and Reliability}

\subsubsection{Reliability}

Consistency of the instrument was examined through the inter-item consistency which uses the popular test Cronbach's coefficient alpha. As sited by Namdeo and Rout (2016) the closer Cronbach's alpha coefficient is to 1.0 the greater the internal consistency of the items in the scale using the rules of thumb if the value of alpha is $>0.9=$ Excellent, $>0.8$ $=$ Good, $>0.7=$ Acceptable, $>0.6=$ Questionable, $>0.5=$ Poor, and $<0.5=$ unacceptable. Thus the reliability was found at high level alpha value.

Table 3.1. Item-total statics

\begin{tabular}{lcc}
\hline Variables & Number of items & Cronbach's Alpha \\
Brokers involvement in supply & 4 & .907 \\
Appropriate Transportation facility & 3 & .865 \\
Price of slaughter animal & 4 & .866 \\
Illegal live animal export & 3 & .877 \\
Quality of animal & 4 & .923 \\
Sustainability of animal supply & 4 & 890 \\
Traditional livestock production system & 4 & .887 \\
Supply performance & 6 & .878 \\
& Overall mean & .887 \\
\hline
\end{tabular}

Source: Field survey 2020

\subsubsection{Validity}

In this study content validity was used to test the validity of the research instrument. The research instruments and the data were reviewed by the experts in the field of research; experience survey was considered and acknowledged. Based on the reviewers' comments the unclear and obscure questions were revised and the complex items reworded. Timely and continuous supervision was made by principal investigator and supervisors. 


\subsection{Data Analysis Techniques}

Correlation analysis was accustomed to analyze relation between independent and dependent variables whereas multiple regressions were applied to analysis and identifies impact level of every independent on dependent variable.

The equation for the study formulated as follows:

$$
\mathbf{S P}=\mathbf{a}+\mathbf{b}_{1}(\mathbf{B})+\mathbf{b}_{2}(\mathbf{T})+\mathbf{b}_{3}(\mathbf{P})+\mathbf{b}_{4}(\mathbf{I})+\mathbf{b}_{5}(\mathbf{Q})+\mathbf{b}_{6}(\mathbf{S})+\mathbf{b}_{7}(\mathbf{T P})+\varepsilon
$$

Where;

$\mathrm{SP}=$ Supply performance of slaughter animal

$\mathrm{B}=$ Brokers involvement in supply of slaughter animal

$\mathrm{T}=$ Appropriate Transportation facilities

$\mathrm{P}=$ Price of slaughter animal

$\mathrm{I}=$ Illegal live animal export

$\mathrm{Q}=$ Quality of animal

$\mathrm{S}=$ Sustainability of slaughter animal supply

$\mathrm{TP}=$ Traditional livestock production system

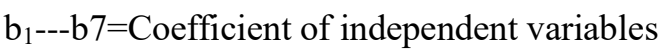

$\mathrm{a}=$ constant

$\varepsilon=$ Error Term

\section{Result and Discussion}

\subsection{Correlation Analysis: Pearson Correlation Coefficient}

The correlation matrix between dependent variable and independent variables are exhibited in table 4.1 below.

Table 4.1. Correlations for independent and dependent variables

\begin{tabular}{lcccccccc}
\hline & CB & CT & CP & CI & CQ & CS & CTP & CSP \\
\hline CB & 1 & & & & & & & \\
CT & -.090 & 1 & & & & & & \\
CP & $.429^{* *}$ & -.018 & 1 & & & & & \\
CI & $.263^{* *}$ & -.105 & .011 & 1 & & & & \\
CQ & .015 & $.268^{* *}$ & .097 & .026 & 1 & & \\
CS & -.097 & .166 & .142 & -.143 & $.411^{* *}$ & 1 & & \\
CTP & -.010 & .148 & .041 & .123 & $.427^{* *}$ & $.473^{* *}$ & 1 & \\
CSP & -.061 & .124 & -.071 & $-.215^{*}$ & $.452^{* *}$ & $.755^{* *}$ & $.580^{* *}$ & 1 \\
\hline
\end{tabular}

$* *$. Correlation is significant at the 0.01 level (2-tailed).

*. Correlation is significant at the 0.05 level (2-tailed)

Sources: Field survey 2020

According to above table 4.1 a two-tailed test of significance indicated that there were a positive and significant relationship between quality of slaughter animal, sustainability of slaughter animal supply and traditional livestock production system with supply performance at $\mathrm{r}(120)=.452, \mathrm{p}<0.000, \mathrm{r}(120)=0.755, \mathrm{p}<0.000$ and $\mathrm{r}(120)=0.580$, $\mathrm{p}<0.000$ respectively. Transportation facility also positively related to supply performance, but not significant since $r$ $(120)=.124, p>.05$. However, brokers involvement in supply and price of slaughter animal were negative and non-significant relationship with supply performance at $\mathrm{r}(120)=-0.061, \mathrm{p}>0.05$ and $\mathrm{r}(120)=-0.071, \mathrm{p}>0.05$ respectively. Also illegal live animal export was negative and significant relationship with supply performance at $r(120)$ $=-0.215, \mathrm{p}<.05$. 


\subsection{Multiple Regression Analysis}

Multiple regression analysis was planned to examine extent effects of supply determinants on supply performance of slaughter animal for meat export abattoirs. The study was investigated the variance predicted by supply determinants on supply performance of slaughter animal for meat exporting abattoirs in Ethiopia which was a dependent variable.

The regression result showed that the predictor (independent) variables have explained $72.1 \%$ of the variability of dependent variable. And $27.9 \%$ of the variation is caused by factors other than the predictors included in this model. The adjusted $\mathrm{R}$ square which is a coefficient of determination shows that, $70.4 \%$ of dependent (supply performance) variable were explained by independents variables and the remaining $29.6 \%$ are explained by other variables out of this model.

The F-ratio in the ANOVA tests whether the overall regression model is a good fit for the data. The independent variables statistically significantly predict the dependent variable, $F(7,112)=41.347, p(.000)<.05$ (i.e. the regression model is a good fit of the data). This indicates that the variation explained by the model is not due to chance.

Table 4.2. Regression Coefficients

\begin{tabular}{llllll}
\hline Model & \multicolumn{2}{l}{$\begin{array}{l}\text { Unstandardized } \\
\text { Coefficients }\end{array}$} & $\begin{array}{l}\text { Standardized } \\
\text { Coefficients }\end{array}$ & $\mathrm{t}$ & \\
& $\mathrm{B}$ & Std. Error & Beta & & \\
& & & & \\
(Constant) & .992 & .131 & & 7.550 & .000 \\
Brokers involvement & -.052 & .049 & .152 & 2.613 & .010 \\
Transportation facility & 127 & .042 & -.066 & -1.250 & .214 \\
Price of slaughter animal & -.233 & .054 & -.243 & -4.287 & .000 \\
Illegal live animal export & -.154 & .039 & -.214 & -3.977 & .000 \\
Quality of slaughter animal & .089 & .041 & .128 & 2.179 & .031 \\
Sustainability of animal supply & .462 & .048 & .593 & 9.672 & .000 \\
Traditional livestock production system & .220 & .046 & .292 & 4.828 & .000 \\
\hline
\end{tabular}

a. Dependent Variable: Supply performance R2 $=72.1, F=41.37, \mathrm{p}<.001$

Source: Field survey 2020

Summary of hypothesis testing

\begin{tabular}{|c|c|c|}
\hline Hypothesis & Statistical test & Result \\
\hline $\begin{array}{l}\mathbf{H}_{1} \text { : Broker's involvement in slaughter animal supply has negative and } \\
\text { significant effect on supply performance of slaughter animal }\end{array}$ & $\begin{array}{l}\text { Multiple } \\
\text { regression }\end{array}$ & Accepted \\
\hline $\begin{array}{l}\mathbf{H}_{2} \text { : Appropriate transportation facility has positive and significant } \\
\text { effect on supply performance of slaughter animal }\end{array}$ & $\begin{array}{l}\text { Multiple } \\
\text { regression }\end{array}$ & Rejected \\
\hline $\begin{array}{l}\mathbf{H}_{3} \text { : Price of slaughter animal has negative and significant effect on } \\
\text { supply performance of slaughter animal }\end{array}$ & $\begin{array}{l}\text { Multiple } \\
\text { regression }\end{array}$ & Accepted \\
\hline $\begin{array}{l}\mathbf{H}_{4} \text { : Illegal live animal export has negative and significant effect on } \\
\text { supply performance of slaughter animal }\end{array}$ & $\begin{array}{l}\text { Multiple } \\
\text { regression }\end{array}$ & Accepted \\
\hline $\begin{array}{l}\mathbf{H}_{5} \text { : Quality of animal supply has positive and significant effect on } \\
\text { supply performance of slaughter animal }\end{array}$ & $\begin{array}{l}\text { Multiple } \\
\text { regression }\end{array}$ & Accepted \\
\hline $\begin{array}{l}\text { H6: }_{6} \text { Sustainability of animal supply has positive and significant effect } \\
\text { on supply performance of slaughter animal }\end{array}$ & $\begin{array}{l}\text { Multiple } \\
\text { regression }\end{array}$ & Accepted \\
\hline $\begin{array}{l}\mathbf{H}_{7} \text { : Traditional Livestock production system has positive and } \\
\text { significant effect on supply performance of slaughter animal. }\end{array}$ & $\begin{array}{l}\text { Multiple } \\
\text { regression }\end{array}$ & Accepted \\
\hline
\end{tabular}

Source: Field survey 2020

Given that, the t-value and corresponding p-value are in the "t" and "Sig." columns (table 4.2), respectively in this study, brokers involvement in supply, price of slaughter animal, illegal live animal export, quality of animal supply, 
sustainability of slaughter animal supply and traditional livestock production system were significant at $\mathrm{p}(0.010)<0.05$, $\mathrm{p}(0.000)<0.01, \mathrm{p}(0.031)<0.05, \mathrm{p}(0.047)<0.005, \mathrm{p}(0.000)<0.01$ and $\mathrm{p}(0.000)<0.01$ respectively. But transportation facility in supply is not significant since $\mathrm{p}(0.214)>0.005$

From the table it can be deduced that, sustainability of slaughter animal supply, traditional livestock production system and quality of slaughter animal were the strong determinant effect factors on supply performance in positive direction with high Beta coefficient respectively. However, price of slaughter animal, illegal live animal export and brokers involvement in supply also have effect on supply performance in the negative direction.

The regression model employed in this study was the following

$$
\mathbf{S P}=\mathbf{a}+\mathbf{b}_{1}(\mathbf{B})+\mathbf{b}_{2}(\mathbf{T})+\mathbf{b}_{3}(\mathbf{P})+\mathbf{b}_{4}(\mathbf{I})+\mathbf{b}_{5}(\mathbf{Q})+\mathbf{b}_{6}(\mathbf{S})+\mathbf{b}_{7}(\mathbf{T P})+\varepsilon
$$

After running this equation, the regression model was as follows:

$$
\mathrm{SP}=0.992-0.052(\mathrm{~B})-0.233(\mathrm{P})-0.154(\mathrm{I})+0.089(\mathrm{Q})+0.462(\mathrm{~S})+0.220(\mathrm{TP})+\varepsilon .
$$

The findings revealed that holding transportation facility, price of slaughter animal, illegal live animal export, quality of slaughter animal, sustainability of slaughter animal supply and traditional livestock production system constant, supply performance of slaughter animal would stand at 0.992 . A unit increase in a quality of slaughter animal would lead to increase in supply performance of animal supply by 0.089 , a unit increase in sustainability of slaughter animal supply would lead to increase in supply performance of animal supply by 0.462 and a unit increase in traditional livestock production system would lead to increase in supply performance of slaughter animal supply by 0.220 . Also a unit increase in brokers involvement in supply would led to decrease supply performance by 0.052 , a unit increase in price of animal would lead to decrease supply performance of slaughter animal supply by 0.233 and a unit increase in illegal live animal export also lead to decrease supply performance of slaughter animal supply by 0.154 .

\section{Conclusion and Recommendation}

\subsection{Conclusion}

From the findings, the following conclusions have been drawn

i. There was a positive and significant relationship between the quality of slaughter animal supply, sustainability of slaughter animal supply and traditional livestock production system with supply performance of slaughter animal for meat export abattoirs. Transportation service also positively related to supply performance, but not significant. However, brokers involvement in supply, price of slaughter animal and illegal live animal export were negative relationship with supply performance of slaughter animal.

ii. Sustainability of animal supply, traditional livestock production system, appropriate transportation facility and quality of animal has strong effect on supply performance in positive direction respectively. However, price of slaughter animal, illegal live animal export and broker involvement in supply also have strong effect on supply performance of slaughter animal for meat export abattoirs in the negative direction respectively.

\subsection{Recommendation}

The annual outflow of live animal from Ethiopia through illicit (informal) market is huge. Therefore the government and stakeholders should work strongly to minimize illegal live animal export to improve supply performance of slaughter animal for meat export abattoirs.

Designated appropriate slaughter animal transportation facility is the problem in Ethiopia. Therefore, it is important to encourage the private sector to participate in slaughter animal transportation service through incentive packages to render slaughter animal transport services using designated trucks to enhance quality, improve animal welfare and to reduce transportation cost of slaughter animal to meat export abattoirs. The government should also provide different incentives (duty free and loan) to slaughter animal supplier to have their own specialized truck to transport animals from the source to the meat export abattoirs

Obtaining quality of slaughter animal (by required age, sex, weight and good dressing percentage) is difficult. Therefore, strengthening animal health service, animal feeding and management system should critically consider improving the quality of slaughter animal to improve supply performance.

Specialized ranches and feedlots may be developed by abattoirs or others interested in commercial livestock production for producing quality animals in large numbers since currently the entire supply of marketed animals come from the smallholder households to overcome sustainability problem. The abattoirs may also consider using contracts as an instrument for sustained delivery of adequate number of quality animals throughout the year. Government should 
improve livestock extension service, animal health system, livestock marketing information, livestock history (traceability) and feeding system and also encourage private sector to engage in livestock extension service to improve livestock production system.

\section{References}

AASTU. (2016). Ethiopian Agro-industry Strategy Meat Industry Sub-Sector Strategic Plan: Addis Ababa, Science and Technology University

Abebe, B, Zelalem, Y, Zerihun, A, et al. (2016). Review on livestock and livestock products and by-products trade in Ethiopia. Developing Country Studies www.iiste.org ISSN 2224-607X (Paper) ISSN 2225-0565 (Online) Vol.6, No.7, 2016

Ameha, S. (2011). Export requirement for meat and live small ruminants: How can development agents assist producers to improve small ruminant export? Techn, Bull,(47).

Anteneh. (2017). Review on Current Status of Small Ruminant Meat Production Comparison Yield and Carcass Characteristics in Ethiopia. Advances in Life Science and Technology www.iiste.org ISSN 2224-7181 (Paper) ISSN 2225-062X (Online) Vol.58.

Asfaw, N., \& Mohamed, J. (2007). Commercial off takes of cattle under smallholder mixed crop-livestock production system in Ethiopia, its determinants and implications for improving live animal supply for export abattoirs. Western Michigan University, Kalamazoo, Michigan, USA.

Belch, G. E., \& Belch, M. A. (2003), Advertising and Promotion: An Integrated Marketing Perspective, 6th ed., McGraw Hill Company.

Creswell, W. (2003). Resarch design: Qualitative, quantitative and mixed approaches, $2^{\text {nd }}$ Edition. Sage publication, California.

CSA. (2017). Report on livestock and livestock characteristics, (Private peasant holdings) Agricultural sample survey, Statistical Bulletin 585, Addis Ababa, Ethiopia, April, 2017

Donald R. Cooper, Pamela S. Schindler. (2014). Business research methods, the $12^{\text {th }}$ Edition, 2014

EMDIDI, (2018). Brochure to promote meat and slaughter by-products exporter profiles, Baskets of Livestock Genetic Resources and Market hub for the world, Ethiopian Meat and Dairy Industry Development Institute, Bishoftu, Ethiopia, 2018.

ERCC. (218/19). Ethiopian Revenues and Custom Commission, annual Report, 2018/19.

Eshetie, T, Hussien, K, Teshome, T, et al.(2018) Meat production, consumption and marketing tradeoffs and potentials in Ethiopia and its effect on GDP growth: a review. Journal Nutritional Health Food Eng. 2018; 8(3):228-233. https://doi.org/10.15406/jnhfe.2018.08.00274

Eyob, E, Zewudu, A. (2016). Review on live animal and meat export marketing system in Ethiopia: challenges and opportunities, Journal of Scientific and Innovative Research 2016; 5(2): $59-64$ Available online at: www.jsirjournal.com

FAO. (2013). Statistical year book.Food and Agriculture Organization of the United Nations, Rome, Italy, 2013. p. 1-307.http://www.fao.org/docrep/018/i3107e/i3107e.PDF

FAO. (2019). World meat market overview, Food and Agriculture Organization of the United Nations, 2019

Gemechu, Tesfaye., \& Gomol. (2019). Major Constraints of Livestock Development, International Journal of Agriculture \& Agribusiness Available online at https://zambrut.com/livestock-development/

Gezhany, D. (2019). Assessment on Impact of Live Animal Export on Meat Export Performance in Ethiopia; Policy Implications. Journal of Business and Management Studies, 5(3). Available online at URL: http://bms.redfame.com

Gichaaga, (2014) Effects of management accounting practices on financial performance of manufacturing companies in Kenya https://www.semanticscholar.org

Göb, R., McCollin, C., \& Ramalhoto, M. F. (2007). Ordinal methodology in the analysis of Likert scales. Quality \& Quantity, 41, 601-616.

Kefyalew, A., \& Tarekegn, A. (2013). Meat and Live Animal Export in Ethiopia: Status, Challenges and Opportunities. Global Advanced Research Journal of Food Science and Technology, 2(4), 054-059.

Kothari, C. (2004). Research Methodology $2^{\text {nd }}$ Edition New age international publication, 4835/24: Ansari Road, 
Daryaganji, and New Delhi.

Philip, K., \& Gary, A., (2014), Principle of marketing, 14th edition, Pearson Prentice Hall.

Mahon, \& Yarcheski. (2002) .Validity and Reliability: What is all about?, Vol. 16, no. 9, unpublished Manuscript.

OECD. (2019). Agricultural Outlook 2019-2028: Organization for Economic Co-operation and Development /Food and Agriculture Organization of the United Nations (2019), "Meat", in OECD-FAO, OECD Publishing, Paris/Food and Agriculture Organization of the United Nations,

Saunders, Lewis, \& Thornill, (2009). Research Method for Business Students $5^{\text {th }}$ Edition.

SPS-LMM. (2010). Focus on Ethiopia's Meat and Live Animal Export. Trade Bulletin Issue 1.The next food revolution. Food, Agriculture and the Environment.

S.R. Namdeo, \& S. D,. Rout. (2016). Calculating and interpreting Cronbach's alpha using Rosenberg assessment scale on pediatrician's attitude and perception on self- esteem. International Journal of Community Medicine and Public Heath, 6, 1371-1374.

USAID. (2010). End market Analysis of Ethiopian Livestock and Meat, 2010

USAID. (2012). Agricultural Growth Program, Agribusiness and Market Development (AGP-AMDe) Project. Submitted by ACDI/VOCA to Contracting Officer' Representative TewodrosYeshiwork, USAID Ethiopia, 2012.

USAID. (2013). US agency for international development progress report of 2013.

Yesihak, Y. M., \& Edward, C. W. (2015). Carcass quality audit, a strategy to improve beef sector in Ethiopia. African Journal of Agricultural Research, 10(28), 2731-2737.

Yin, K. (2003). Case study research design and methods $3^{\text {rd }}$ Edition, Sage publication, Thousand Okas, London, 2003.

Yishak. (2009). Determinants of Ethiopia's export performance: a gravity model analysis, Trade and development discussion paper no. 01/2009,Munich, June 2009.

\section{Copyrights}

Copyright for this article is retained by the author(s), with first publication rights granted to the journal.

This is an open-access article distributed under the terms and conditions of the Creative Commons Attribution license which permits unrestricted use, distribution, and reproduction in any medium, provided the original work is properly cited. 